\title{
REVISITING KHILĀFAH: THE ROLE OF NONPOLITICAL SOCIAL FACTORS IN GOOD GOVERNANCE
}

\author{
Abdul Kabir Hussain Solihu*
}

\begin{abstract}
Khiläfah has been a symbol of the Muslim political system and Islamic politics has often been identified as Khiläfah in the same structure it took form in the past. This study argues that Muslims exhausted their energy on political discourse at the expense of other factors which are important for preparing the ground for political maturity. An attempt is made to exhibit normativeness of the Islamic political principles and values and the historicity of the form (Caliphate) it has acquired over the course of Islamic history. Furthermore, greater emphasis is placed on the broader, civilisational sense of Khiläfah under which the political sense of Khiläfah (Caliphate) is subsumed. In doing so, the study aims to contribute to the discourse on the revitalisation of the contemporary Muslim political culture but through non-political means.
\end{abstract}

\section{Introduction}

Khiläfah, as a system of political leadership, is probably the most important institution in Islamic civilisation. It stands as a symbol of Muslim unity under a supreme political leader of the Islamic state who takes charge of the Ummah in all its affairs. Despite their inheritance of fourteen centuries of experience, many Muslim nation-states today are facing unprecedented political crises, contributing to their instability and underdevelopment. The cause of this adversity cannot be simply attributed to the fall of Khiläfah (Caliphate) in 1924; rather, its genesis can be traced back to many centuries earlier.

This study aims to investigate the Muslim political culture, where Islamic politics has been identified as Khiläfah in the form that it took shape in the past; and where Khiläfah has been submerged by the political discourse. It sets out to disentangle this longstanding vexed attitude. The study is divided into four parts. Part one highlights the importance and the place of political leadership in Islam. This part should not be understood in isolation. Part two explores how political discourse has dominated Muslim history at the expense of other infrastructures. To disentangle the Islamic political system from the way it has crystallised in Muslim history is the central theme of part three. This part thus exposes the historicity of political Khiläfah. Part four examines the general civilisational sense of Khiläfah. It places emphasis on the need to readdress political Khiläfah, subsuming it under a more imperative discourse on Khiläfah as a civilisational mechanism. The study aims to contribute to the discourse on the revitalisation of the Islamic political system through non-political means. 


\section{The Place of Political Leadership in Islam}

One should not underestimate the importance of politics in Islam. Prophet Muhammad (peace be upon him) is reported to have said: "when three are on a journey, they should appoint one of them as their commander." The authority of those in power or their right to be obeyed is often drawn from a Qur'anic verse that says: "O you who believe! Obey Allah, and obey the Messenger, and those charged with authority among you" (4:59).

It is undeniably true that many Islamic teachings cannot be observed without a well established political system. The practices of al-amr bi al-ma' $r u \bar{f}$ wa-alnahy 'an al-munkar (enjoining the virtues and forbidding the vices), undertaking $j i h \bar{a} d$, upholding justice at all levels, administering Islamic law and other codes of life and actions require a central unit that oversees the observation of these principles. ${ }^{2}$ Hence, the Prophet is reported to have said that "it is obligatory upon a Muslim that he should listen (to the ruler appointed over him) and obey him whether he likes it or not, except that he is ordered to do a sinful thing. If he is ordered to do a sinful act, a Muslim should neither listen to him nor should he obey his orders." According to Ibn Jamā'ah (d. 733/1333), the appointment of an Imām (another title for a political leader) is necessary to protect religion, to administer Muslim affairs, to restrain the aggressive nature of man, to repulse enemies, to obtain justice for the oppressed, to collect taxes and administer their proper expenditure and, above all, to secure and maintain order and stability in society. ${ }^{4}$ For that, the rank of a just sultān is believed to be very high, next to the prophet and angels. ${ }^{5}$ Al-Ghazālī (d. 505/1111) also explained that the establishment of a sultān has the sanction of the Sharī ah because worldly affairs cannot be organised without a leader and the organisation of worldly affairs is an essential prerequisite to the organisation of religious affairs necessary for the attainment of success in the hereafter. ${ }^{6}$

The establishment of political leadership in the Muslim community has been considered as fard kifäyah (collective duty) like jihād. Once it is exercised by qualified persons, it ceases to be binding upon others, simply because only a few people have the expertise in this field among whom only one person will be selected as Khaliffah (Supreme Leader). ${ }^{7}$ To consider the institution of leadership as fard kifäyah is to consider revelation, backed by $i j m \bar{a}^{\prime}$ (unanimous consensus), as the source of its foundation. This is the view of the overwhelming majority of the Sunnite scholars. ${ }^{8}$ Mu tazilites, however, considered reason as its source. According to Ibn Taymiyyah ${ }^{9}$ and Ibn Khaldūn (d. 808/1406), ${ }^{10}$ both revelation and reason make political leadership necessary.

Even though it is fard kifāyah, Khiläfah still remains within the parameters of a social contract, according to Sunnite political thought. It is more related 
to fiqh (Islamic Jurisprudence) than Ușül al-Din (theology or fundamentals of Islamic faith). ${ }^{11}$ Ironically, it is more often discussed, even by Sunnite scholars themselves, in books dealing with Ușül al-Dīn than books dealing with fiqh. ${ }^{12}$

\section{Khiläfah and Its Political Discourse}

Discourse on political Khiläfah and other related issues has considerably dominated Islamic scholarship throughout Islamic civilisation. It has been addressed in theological circles as well as jurisprudential quarters. Al-Shahrastānī (d. 548/1153) considered it the most disputed topic among the Muslims. ${ }^{13}$ Maḥmūd 'Abd al-Majīd al-Khālidī acknowledged that "the post of Khiläfah has preoccupied all Muslims worldwide in the past and present." ${ }^{\prime 14}$ Hamilton A. R. Gibb (d. 1971), one of the twentieth-century's leading Orientalists, also pointed to the Muslims' curiosity and preoccupation with political discourse. Writing on alMāwardī's (d. 450/1058) theory of the Caliphate, he observed that "almost every succeeding generation left its mark upon political doctrine, as fresh precedents were created and the theory was accommodated to them." 15

Within Islamic political philosophy, many questions related to political Khiläfah have been raised: How to set up Khiläfah? What is the proper title of Khalīfah - Khalīfat Allāh or Khalīfat Rasūl Allāh? What is the definition of Khiläfah and how to appoint Khalifah? What are the characteristics and the qualifications for the post of Khiläfah and what are the limitations of obedience to Khaliffah? In all these tremendous endeavours, we have taken it for granted that our approach to Khiläfah is conclusive. This has led many to regard both the Islamic political system and Khiläfah as synonymous. Consequently, Khiläfah has been generally considered as the substance and the backbone of Islamic leadership, and thus for many becomes the only acceptable political system in Islam. ${ }^{16}$

Take for example how Maḥmūd 'Abd al-Majīd al-Khālidī, a contemporary Muslim political analyst, treated "the authoritative source of the post of Khiläfah" (sanad manșib al-Khiläfah). He first mentioned ten different definitions of Khiläfah, none of which, according to him, seemed to be accurate. Then he quoted three popular views commonly attested to by Muslim scholars on the source of the post of Khiläfah that it is: (1) a representative of God, (2) a representative of the Prophet and (3) a successor of a predecessor. ${ }^{17}$ Then he proceeded to disqualify them one by one. The first view affirmed that Khalifah is God's representative on earth, relying on the general Khiläfah role given to humankind as stated in the Qur'an 2:30; 6:165. According to al-Khālidī, this view is wrong on two grounds: first, the Qur'anic quotation is irrelevant because the discussion is on the source of the post of Khiläfah which is "general leadership over all Muslims in this world to implement Islamic Shari 'ah and to convey the Islamic call to the world", not in the general sense of Khaliffah"; and secondly that only an absentee 
can be represented but God is ever present. The second view was based on the saying attributed to Abū Bakr when he refused to be addressed as 'Khalīfat Alläh' and preferred, instead, the title of 'Khalīfat Rasūl Allāh'. Al-Khālidī considered this evidence to be wrong because the Prophet did not appoint Abu Bakr as his representative and the Ummah has no right to appoint somebody as a representative of another, but only as a representative of themselves. The third view relied on the literal-grammatical sense of Khilāfah, meaning 'succession'. Al-Khālidī rejected this view on the grounds that the grammatical meaning is insufficient and irrelevant to the discussion on sovereignty. Then he came out with his own view that Khalifah is a representative of the Ummah. It is primarily the Ummah that possesses the sovereignty. But when the Ummah elected a Khaliffah to maintain sovereignty and implement Islam in all walks of life, they then deposited their right with him, making him their representative to maintain sovereignty. ${ }^{18}$

In his analysis, al-Khālidī has confined the concept of Khalīfah to political ideology. What is disputable in this discussion is not how he discredited the opposing views but the very premise and foundation upon which he based the whole discussion, that is, on "the authoritative source of the post of Khiläfah". Had he made his starting point the grammatical sense or the Qur'anic use of the term, as will be explicated in the last part of this article, he would have appreciated better the last two views that he discredited.

It has been well established that history means different things to different people. What counts in history, upon which national or world history usually stands, is generally what is believed to be unique, which arrests the attention of its observers. However, what is considered "unique" is a question which different people would answer in different ways. For some, it is the economic revolution; for others it is intellectual progress; still for others, it is the heroic period. As for Muslim history, it is the political regime that has been given the priority. Hence, the periodisation of Muslim history is based on political regimes and empires. After the period of Khulafä' al-Rāshidūn (the Rightly Guided Caliphs), there were the Umayyad Dynasty (661-750), Abbasid Dynasty (750-1258), Muslim rule in Andalus (711-1492), Fatimid Dynasty in North Africa (909-1171), Ayyubid Dynasty (1171-1250), Turkish Mamlūk Dynasty (1250-1517), Mughal Dynasty in India (1526-1857), Ottoman Empire (1326-1924), and the modern Muslim states (1924-). Under this political hegemony, other intellectual, theological, juristic and artistic movements are subsumed. This gives an impression that what matters most is the politics.

In the early part of the twentieth century, just a few years before the eventual abolition of the Ottoman Empire, there was a serious political campaign known as the Khiläfah movement. Mawdudi and Rashid Ridah, among others, made serious but unsuccessful attempts to reconceptualise modern democracy under the 
Khiläfah frame of reference. In particular, Mawdudi called for the Islamisation of the state through the Islamisation of society. Once the population are fully aware of the Islamic values, they would be willing to embrace the Islamic Khiläfah system of governance. Such campaign, however, was not well planned/executed and/or not well received even in regions where it was more popular. ${ }^{19}$

The institution of Khaliffah requires three basic principles to be maintained. They are: to uphold the unity of the Muslims, to retain divine guidance and to lend both unity and guidance a new continuity. During the Abbasid period, unity came to mean strict political unity under a single Caliph; divine guidance came to mean divine right; and historical continuity came to mean the hereditary right of the Abbasids to the caliphal throne. ${ }^{20}$

Even after the fall of the Caliphate system, some of these principles continue to be maintained, if only nominally. Several monarchies are adept at manipulating Islamic symbols to their own advantages. The Moroccan king, for example, had made much of his traditional title, Amir al-Mu'minin (the Commander of the Faithful). The Saudi king spoke of his role in protecting Makkah and Madīnah and thus was proud of having the title of Khadim al-Haramayn (the custodian of the two holy mosques). Jordanian kings claimed Hashimite descent traced back to Prophet Muhammad. ${ }^{21}$ During the first Gulf War in 1991, Saddam Hussein of Iraq also claimed descent from the Prophet in order to win the hearts of Muslims worldwide against the Western coalition.

The unity of all Muslims was taken, to a large extent, in a political sense based on hereditary monarchy, and invoked to favour the ruling regime instead of nurturing a political culture. ${ }^{22}$ As a result, there has been manoeuvring by many political leaders to disband the political opposition and to instil a culture of acquiescence with the absence of outright political opposition to the ruling regime.

On closer examination, it could be found that sometimes, the quest for political unity (at least as it has been generally experienced) has been more a bane than a boon. This can be demonstrated by comparing political with non-political discourses. At the intellectual, theological-philosophical, jurisprudential, Sufi and literary levels, Muslims produced a rich and unsurpassed legacy. There were as many arguments as there were counterarguments. Some raised critical questions, to which others produced appropriate answers. Yet, there were still others who questioned the premises of both the questions and the answers produced by their predecessors. This came about as a result of liberty and freedom of thought and expression. Such discourses were often arrested at the political plane and opposing views to the political ideology of the ruling regime were silenced and their protagonists tortured or even executed.

Non-political discourses, however, despite their intensity, never led to war. It is primarily on the plane of leadership that Muslims were feuding. When 
recounting the difference of opinion that crept into the early Muslim community, al-Shahrastānī admitted that political dispute was the most ferocious. As he put it, "the greatest dispute, indeed, in the community has been that over the Imamate; for no sword has ever been drawn in Islam on a religious question as it has been drawn at all times on the question of the Imamate." ${ }^{23}$

It is true that Islam promotes unity, but such unity is not necessarily confined to political unity. Non-political unity, such as social cooperation, economic interdependence, and cooperation among different institutions and NGOs, could provide alternatives to political unity. The idea that non-political Khiläfah or non-political unity could supplement or even supplant political Khiläfah in uniting the Ummah has attracted some Muslim scholars. Presenting his paper to the Organisation of Islamic Conference, Abū Zahrah acknowledged that Muslim unity is divinely imperative $(3: 103){ }^{24}$ However, he did not believe that such unity could be achieved through the institution of Khiläfah due to many factors. The geographical distribution of the Muslim world, in particular, will make the institution of Khiläfah, with one single state as it previously was during the period of the Rightly Guided Caliphs, impractical. According to him, the unity should take different forms, compatible with the spirit of the age (rüh al- 'așr), such as economic, political, military and cultural cooperation. Khiläfah can partake in the new project of unity, as a symbol but not as its cornerstone. ${ }^{25}$ However, such an insightful proposal is not popular among the great majority of Muslims and had even been ridiculed by some writers. ${ }^{26}$

\section{Historicity of Political Khiläfah}

That Islam sanctioned political leadership and blessed it with divine grace is one thing; that Khiläfah is that political leadership or the only political system approved in Islam is quite another matter. Both need to be disentangled. The term khiläfah is a verbal noun derived from khalafa which means 'to come after, to follow, to succeed, or to remain after another that had perished.' Khalf is a noun which means 'behind' (in place), but this easily passed into 'behind' (in time) or 'after'. The phrase ' $j a \bar{a}$ ' $a$ khalfahu' means 'he came behind him or after him.' Khaliffah is a successor, deputy or vicegerent who has been made or appointed to take the place of the one who has been before him. The plural is khulafä' and khala 'if (caliphs). ${ }^{27}$ Al-Rāghib al-Iṣfahānī (d. 502/1108) explained that Khiläfah signifies one's representation of another, either because this other is dead or incapacitated, or simply to honour the representative. In this last sense, God has made the righteous people (awliyā'ahu) His khalä'if on earth $(6: 165 ; 35: 39) .{ }^{2}{ }^{28}$ Looking for the broadest meaning of Khaliffah within the political parameters, some modern writers extend the scope of Khalifah to include personal, interpersonal and societal sectors. Man is Khalif $f$ h over himself 
because he is required to control himself, Khaliffah over others because he must render justice to other beings, and Khaliffah over the community because he is required to govern them, all following the divine command. ${ }^{29}$

Technically, Khiläfah refers to the institution of governance, based on the Qur'an and the Sunnah, which took form after Prophet Muhammad (pbuh) to serve the objective of looking after the affairs of the Ummah, establishing the commandments of the Shari 'ah and continuing the mission of the Prophet in all walks of human life. ${ }^{30}$ In a political context, Khiläfah has been defined as "vicariate of the prophecy in upholding the faith and managing the affairs of the world" ${ }_{31}$ or "to represent the bearer of Shari' 'ah (șăhib al-shar") [Muhammad pbuh] in the protection of religion and the government of the world. ${ }^{32}$ Construed in that sense, Khalifah is to supervise the interests of the Ummah in all the affairs of life. ${ }^{33}$

There are some other terms also used to refer to an Islamic state and to the head of that state. Imārah designates an emirate and Amīr refers to the emir or head of state; in this sense 'Umar ibn al-Khatțāb was conferred the title of Amìr alMu'minin (Emir of the believers). Al-imämah (the Imamate) was used to refer to Islamic political leadership and Imām to the leader of the Islamic state ${ }^{34}$ (as well as a leader in prayer). Sultān also refers to a Muslim head of state..$^{35}$ However, no other term enjoyed the same popularity as Khiläfah and Khalïfah.

The first person to be referred to as Khalïfat Rasūl Allāh was Abū Bakr, the first Caliph after the Prophet (pbuh). It is related that he was first conferred with the title of Khalīfat Allāh, but preferred and eventually accepted Khalīfat Rasūl Alläh instead. ${ }^{36}$ Since then Khiläfah has become the official designation of the Muslim state/sovereignty and Khalīfat Rasül Allāh or al-Khiläfah for the head of the state. ${ }^{37}$

While political leadership is central to Islamic Sharī'ah, the form it has acquired in the course of history is rooted in specific historical settings. Khiläfah as a political institution symbolised the unity of the Muslim Ummah and worked perfectly in the early decades of Muslim history, thanks to the commitment of the Rightly Guided Caliphs. Nevertheless, it emerged from an entirely particular historical context. Nowhere in the primary sources of Islamic legislation (i.e. the Qur'an and the Sunnah) was Khiläfah divinely sanctioned as the only approved political system for the Muslim Ummah. In addition, the Qur'an and the Sunnah lay down no specific method of choosing a Khaliffah. The only relevant reference in the Qur'an is related to the people whose affairs are decided in the form of shürā (consultation) amongst themselves $(3: 159 ; 42: 38)$, potentially including the selection, appointment, removal, or replacement of a ruler. Obviously, this is consultation and not a definite procedure for appointing a leader of the state..$^{38}$

It must be recognised that the doctrine of Khiläfah, as eventually worked out, represented an interpretation of the sources of revelation in the light of 
later political developments. We must not lose sight of the difference between the divine text and its interpretation in a particular historical setting. Khiläfah derives much from the experience of the four Rightly Guided Caliphs. It also embodied formulas gained through later political developments. The disputes over the Imamate during the civil war, the seizure of power by Mu'âwiyah ibn Abī Șufyān, the polemics between the Umayyads and 'Abbasids, and their impact on the theological movements, all left their imprints on the theory of Caliphate. While some jurists attempted to adapt the principles upon which the society was supposed to be built, others chose to accommodate new circumstances to the existing principles and theories. ${ }^{39}$ Take for example the question of parallel Khiläfah. Initially, it was not acceptable to establish a parallel Khiläfah or to have more than one Imam. Imam al-Nawawī, al-Māwardī, Abū Ya 'āa and Ibn Jamā'ah denied the legitimacy of the existence of two Imams at a time in one territory or two territories. However, al-Ash 'arī, al-Baghdadi and Ibn Taymiyyah allowed for the existence of more than one Khalifah, provided that their territories are far from each other. ${ }^{40}$ Obviously both views are not dissociated from historical precedents or their contemporary political experience (the Umayyad Khiläfah in Andalus/Spain existed simultaneously with the Abbasid Khiläfah in Baghdad).

It was only during the course of its evolution, after the Prophet (pbuh) passed away, that the term started to designate an exclusive political dimension. That the interpretation and application of the text took place in the light of unfolding events in history puts political Khiläfah on a historical plane, not on a doctrinal plane. ${ }^{41}$ Thus, it is entirely a historical form devised by the early Muslims, out of their $i j t i h \bar{a} d$, to designate a political system for Muslims. However, as lived and experienced during the period of the Rightly Guided Caliphs, khiläfah has become a reference point of how the Prophet's successors governed and the principles they applied, many of which are still relevant to governance of today.

Historicising Khiläfah, as displayed in this study, is not necessarily tantamount to secularism. Indeed, Islam recognises no separation between religion and state. As al-Ghazālī stated, religion and state are like twin sisters; religion is the foundation of human society and the ruler is its protector. A society without a foundation would collapse and without a protector would go astray. ${ }^{42} \mathrm{Ibn}$ Taymiyyah also considered the exercise of power through the institution of Imamate as a religious duty, one of the supplications by which man draws near God. ${ }^{43}$ Contrary to the view that Islam is purely religious, indifferent to or devoid of political interest, as claimed by Muslim secularists ${ }^{44}$ it certainly provides several political principles needed to be observed at micro-organisational and macro-political or international levels. This includes the necessity of shürā, the primacy of Shari ' $a h$, the establishment of justice amongst people, and the pursuit of the public interest. ${ }^{45}$ These principles were, to a large extent, embodied in the 
Khiläfah system as it existed during the period of the Rightly Guided Caliphs.

However, to attempt to set up Khiläfah as it exactly existed in the past is extremely difficult and unrealistic. Realising the cultural and geographical heterogeneity of the Muslim world today, some Muslim political theorists have suggested a flexible federation type of government that would engage the populace in politics at local, state and central levels. AbdulHamid A. AbuSulayman, former Rector of the International Islamic University Malaysia, observed:

The Islamic premises to Islamic political science and Islamic political action need to transgress the present understanding of Khilāfah as merely a historical institution which needs to be copied and practiced in the same way that it was practiced by the early generations of Muslims. Instead, Khiläfah should be understood as a dynamic system... Whatever system of government the Ummah chooses for itself in order to realise its spiritual and temporal aspirations is the one that should be understood as the Khiläfah system, and thus deserving of the Ummah's support. Students should pay no attention to historical forms, because to adhere to forms while ignoring the essence is the result of inexperience. ${ }^{46}$

It should be realised that politics is dynamic and changing, not stagnant. It is true, as Harvey Cox says, that "significant political and social change is almost impossible in societies in which the ruling regime is directly legitimated by religious symbols, in which the ruler is believed to be divine" but it is not true that "political change depends on a previous desacralisation [secularisation] of politics. ${ }^{47}$ Certainly, political foundations may continue unchanged, but may be actualised in different forms in the course of historical change. This is where the normative Islamic political system stands.

\section{Civilisational Khiläfah}

In the contemporary political context, we need to address such questions as 'what makes politics?', 'what makes politics Islamic?' and 'what makes Islamic politics?' These questions need to be subsumed under a more general and more important question: 'what makes Khiläfah?' Indeed, good economic standards, societal maturity, intellectual ripeness, natural exploration, spiritual uplift and the proper management of human resources, among other factors, create conditions in which a sound political system grows and prospers.

It would be instructive to highlight how political science is rooted in the human sciences and social sciences, especially psychology, economics and sociology. Psychology, particularly social psychology, contributes much to politics. It helps political science to understand why and under what circumstances people obey authority; and how people form national, group and voting attachments. ${ }^{48}$ Therefore, psychological concerns precede political questions. 
Economics is also one of the elements of politics. According to Schwartz, it is inequality grown from differences among the social strata that created the political world. Politics arises from a collectivity's experiences of uneven distribution of socially valued resources and the pressures those experiences create towards responsive actions. Therefore, "if all valued resources were distributed equally and there were no way for some people to get more than others, there would be no political problem."

The social basis of politics is of such monumental significance that politics is often defined in social terms as "the way in which we understand and order our social affairs." ${ }^{50}$ It has been widely accepted in political science that society is the underlying element in the study of politics and is the proper starting point for political analysis. That is, we assume that politics grows out of society. One starts with people's values, attitudes and opinions and then sees how they influence politics. Yet, given Islam's holistic nature and its source of reference, where revelation plays a crucial role (Qur'an, 5:44, 45, 47), people need to be molded with the Islamic values so that they may support a government that rules in accordance with these values.

Ibn Taymiyyah (661-728/1263-1328) made it clear that the establishment of political leadership is a prerequisite for human development, yet it is the sociability of human nature that makes political leadership necessary:

None of mankind can attain to complete welfare, either in this world or in the next, except by association (ijtimā'), cooperation, and mutual aid... For this reason it is said that 'man is a political being [madani] by nature.' But when they unite together (ijtama' $\bar{u}$ ) there must of necessity be certain things which they do to secure their welfare and certain other things which they avoid because of the mischief which lies in them, and they will render obedience to the one who commands them to the attainment of those objects and restrains them from those actions of evil consequence. ${ }^{51}$

Ibn Khaldūn also made a similar point that humankind is naturally social and ipso facto requires a leader who can control the aggressiveness that naturally arises from human nature:

Social organisation is necessary to the human species. Without it, the existence of human beings would be incomplete... When mankind has achieved social organisation, as we have stated, and when civilisation in the world has thus become a fact, people need someone to exercise a restraining influence and keep them apart, for aggressiveness and injustice are in the animal nature of man. ${ }^{52}$

Much earlier, Aristotle has defined man as "zoon politikon" which has been generally translated as "a political animal" 53 but can also mean "a social animal". The fact is that the Greeks lived in city-states in which the polis was the same as 
society. What Aristotle meant, as Roskin explains, is that humans live naturally in herds and thus they need each other for survival and sustenance. It is also natural that they array themselves into ranks of leaders and followers, like all herd animals. ${ }^{54}$

Thus, it is primarily a consequence of social interactions between individuals and groups that a mechanism to administer these interactions emerged, so giving rise to the institution of politics. It is under the umbrella of the social sciences that the study of politics has become firmly enshrined. ${ }^{55}$ 'To know how to rule' is preceded with 'to know whom to rule.' A ruler needs to know the psychology, anthropology, history and reality of the society of the ruled before he can rule them properly. Hence, the proper administration and maintenance of, for example, the social, psychological and economic substructures upon which politics is built, alongside the politics itself, is on what Khiläfah primarily stands. It means the creation of proper economic management, political administration, social and psychological welfare, spiritual uplift and sustainable development of human and natural resources in line with the Islamic worldview. 'Abd al-Majīd al-Najjār explained that the responsibility of Khaliffah requires man to engage with the universe with both his spirit and body, both of which are congruent with his nature. The spiritual engagement with the universe is to receive, observe and implement God's guidance which makes up the constitution of Khiläfah; and the material engagement with the universe is to build and develop the earth in accordance with that divine constitution. So everything one does, both spiritually and materially, to get closer to God is the requirement of Khiläfah as is largely used in the Qur'an. ${ }^{56}$

There is only one ayyah that specifically refers to Khalifah, in the sense of political leadership, which relates to Prophet Dāwūd: "O David! Surely We have made you a Vicegerent on earth; so judge between men with justice and do not follow desire, lest it should lead you astray from the path of Allah" (38:26). However, it is used in non-political senses in many more places. There is, at least, one verse that uses Khiläfah in a purely economic not a political sense where it is stated "Believe in Allah and His messenger, and spend (in charity) out of the (substance) whereof He has made you mustakhlafin (trustees)." In this verse, the Qur'an uses the word "mustakhlafin", derived from Khiläfah. Abu Hayyān al-Gharnāți (d. 745/1344) mentioned that there were two different views on the exact thing on which Ādam was Khaliffah, that is the duty of Ādam as God's Vicegerent: "first, to judge with truth and justice" and secondly "to develop the earth by sowing and reaping, and by constructing and making the rivers flow." ${ }^{57}$

On that ground, humankind may be referred to as Khaliffat Alläh on earth in a civilisational sense of the term, and not in the sense of replacing an absent or a dead god. The phrase should not imply 'deputyship of God', as Patricia Crone suggested, ${ }^{58}$ in the sense that man is divinely inspired to rule (theocracy) 
in such a way that will make his political and legal decisions infallible; such an idea is inimical to Sharī $a h$, at least as elaborated in Sunnite Islam. It should be understood in the sense that human beings manage the affairs of many creations entrusted to them by God. In his book al-Khiläfah fi al-Arḍ, Aḥmad Ḥasan Farḥāt supported al-Rāghib al-Ișfahānī's view that the righteous are the honourable khulafä' Allāh on earth. They represent God, while He is still Omnipresent and Omniscient, in maintaining His creations. ${ }^{59}$ They represent Him not only in terms of ruling, but also in everything entrusted to them. When commenting on the verse: "Behold, thy Lord said to the angels: 'I will create a Khaliffah on earth'." (2:30), Ibn Isḥāq explained that the verse means Allāh will create a "sākinan (inhabitant) and "Amiran (developer) who will inhabit and develop the earth." ${ }^{\circ 0}$ Humankind is highly esteemed and raised above many other creations which are made subservient to him by God, as stated in many Qur'anic verses (14:32-34; 16: 12-18; 17:70; 21:30-33; 27: 60-61; 28: 71-73). Having been endowed with this unparallel status, humankind is, as 'Abd al-Raḥmān al-Maṭrūdī observed, qualified to be Khalīfat Allāh on earth. ${ }^{61}$

\section{Conclusion}

Throughout Muslim history, we have invested all-out efforts in political discourse. Through our obsession with governance, we relegated one of the most important concepts in the Qur'an which represents man's mission on earth, to political discourse, making us unable to see it in its wider scope. This tendency exhausted our energy so that we could not adequately pay attention to other factors which are the substructures of politics, primarily responsible to prepare the grounds for political maturity. This study attributes our contemporary political crisis to our perpetual preoccupation and obsession with politics.

Of all human related factors, what then make a sound political system are mainly the non-political factors. To assume that politics makes politics is to "beg the question" and to suppose that politics makes non-political sciences is to put the cart before the horse. Politics is made and it does not make. It is a fruit, not a root. Muslims need to invest efforts in creating conditions suitable for the growth and sustenance of a sound political system. A sound political system is the culmination of non-political factors which in turn can further enhance these non-political factors. The proper management of all these factors (including governance) is the duty of God's Khaliffah on earth, as can be understood from the Qur'an.

The study argues further that the institution of political Khiläfah is a form of governance which embodied Islamic political principles, particularly during the period of the Rightly Guided Caliphs. Being a historical form of political leadership, Khiläfah, as it existed in the past, is not binding upon the subsequent 
generations unless that form of governance meets and resonates with their needs.

It is one thing to make the present live in the past; it is quite another to make the past live in the present. To set up the Khiläfah institution exactly as it used to be, irrespective of the contemporary socio-political realities, is a way of making the present live in the past. To engage Islamic political principles (shūra $/$ consultation, good governance, etc.) as they have been expounded in the Qur'an and Prophetic Sunnah, in the contemporary socio-political culture is a way of making the past live in the present. The study recommends that Muslims should jeer the first strategy and cheer the second strategy.

The following are some key policy recommendations in the field of Islamic governance:

- Primacy of Islamic Values: Muslim scholars should educate people on the necessity of living Islamic values and supporting a government that prioritises Islamic values. Muslim policymakers should promote non-governmental social organisations that promote national interests and integrate Islamic values in their activities.

- Alliance of Interests: National interests that transcend party politics and fleeting political regimes should be aligned with the Islamic values shared by other Muslim majority countries. A political regime is elected or deposed based on the extent to which it serves the national-cum-transnational (ummatic) interests.

- Linkage among the Muslim Majority Countries: In establishing a linkage among the Muslim majority countries, due emphasis should be placed on nonpolitical social institutions that sustain any viable government. Capitalising on the common interests and shared values that connect people of diverse cultural backgrounds, Muslim leaders should invest in creating an enabling environment for social cooperation, economic exchange, joint research collaboration, and institutional partnership among the Muslim majority countries.

- Religion and Politics: There is a need to recognise the centrality of political leadership in the Islamic system. To divest Islam of its longstanding political ideal is to expose its core values to anarchy. Secularism can hardly prosper in a religious culture in which engagement in all walks of life is seen as an existential value and act of 'ibādah (worship).

- Openness and Flexibility: As a way of life, suitable for all places and times, Islam is not closed to historical inventions and does not retard the path to progress. The Muslims should be prepared to see, with dispassionate eyes, possible new political forms that history has withheld in its rich treasury for its inquirers, and to study how such forms could be no less Islamic than the institution of Khiläfah. 


\section{Notes}

* Abdul Kabir Hussain Solihu is an Associate Professor, Faculty of Islamic Revealed Knowledge and Human Sciences, at the International Islamic Universtiy Malaysia (IIUM). He took his B.A. in Arabic \& Islamic Studies from Al-Azhar University in 1993 (Cairo); and M.A. and Ph.D. degrees from IIUM (1998 and 2003). He specialises in Islamic Thought, Comparative Religion and Hermeneutics, has published on computational linguistics, and serves as Editor of IIUM's journal Intellectual Discourse.

1. Abū Dāwūd, Sunan Abī Dāwūed, ed. Muhy al-Dīn 'Abd al-Ḥamīd (Beirut: Dār Ibn Ḥazm, 1997), Kitāb al-Jihād, hadīth no. 2608, 3:58; Sunan Abu Dawud: English Translation with Explanatory Notes, trans. Ahmad Hasan (Lahore: Muhammad Ashraf, 1984), Kitāa al-Jihād, 2:721.

2. Taqī al-Dīn Ibn Taymiyyah, Al-Siyāsah al-Shar'iyyah fì Ișlāh al-Ră' $\bar{\imath}$ wa-alRa`iyyah (Saudi Arabia: Wizārat al-Shu'ūn al-Islāmiyyah, 1418H), 168.

3. Muslim, Șah̄ịh Muslim, ed. Muhammad Fu'ād 'Abd al-Bāqīi, $2^{\text {nd }}$ ed. (Beirut: Dār al-Kutub al-'Ilmiyyah, 2003), Kitāb al-Imārah, 12:191; Șaḥ̄h Muslim, trans. 'Abdul Hamīd Șiddīqī (New Delhi: Kitab Bhvan, 1978), Kitāb al-Imārah, Book xviii, 3:1022.

4. Ibn Jamā’ah, Tahrī̄r al-Aḥkām fì Tadbīr Ahl al-Islām, eds. Aḥmad Farīd al-Mazīī̄ and Muhammad Hẹasan al-Shāfi 'ī (Beirut: Dār al-Kutub al- 'Ilmiyyah, 2003), 15.

5. Ibn Jamā'ah, Tahrìr al-Aḥkām, 16.

6. Abū Ḥāmid al-Ghazālī, Al-Iqtișād fì al-I tiqād (Beirut: Dār al-Kutub al'Ilmiyyah, 1983), 148-149.

7. 'Alī ibn Muhammad al-Māwardī, Al-Ahkām al-Sulțāniyyah wa-al-Wilāyāt alDiniyyah (Cairo: Dār al-Fikr, 1983), 5-6; The Ordinances of Government: A Translation of al-Aḥkām al-Sultāniyya w' al-Wilāyāt al-Dīnīyya, trans. Wafaa $\mathrm{H}$. Wahba (Reading, UK: Center for Muslim Contribution to Civilization, 1996), 4.

8. Al-Ghazālī, Al-Iqtișād fì al-I' tiquād, 147, 149; 'Abd al-Razzāq Ahmad al-Sanhūrī, Fiqh al-Khilāfah wa-Tațawwuruhā, ed. Tawfīq Muhammad al-Shāwī and Nādiyah 'Abd al-Razzāq al-Sanhūrī (Beirut: Mu'assasat al-Risālah, 2001), 81.

9. Taqī al-Dīn ibn Taymiyyah, Al-Hisbah fì al-Islām (Beirut: Dār al-Fikr al-Lubnān̄̄, 1996), 6; Ibn Taymiyyah, Al-Siyāsah al-Shar'iyyah, 168.

10. 'Abd al-Raḥmān ibn Khaldūn, Muqaddimat Ibn Khaldūn (Beirut: Dār al-Qalam, 1984), 191-192; The Muqaddimah: An Introduction to History, trans. Franz Rosenthal (Princeton: Princeton University Press, 1967), 1:388-390.

11. Al-Ghazālī, Al-Iqtișād fì al-I 'tiquàd, 147.

12. Ibid.; al-Sanhūrī, Fiqh al-Khilāfah, 62-63.

13. Muhammad ibn 'Abd al-Karīm al-Shahrastān̄̄, Al-Milal wa-al-Nihal, ed. Muhammad Sayyid Kaylānī (Beirut: Dār al-Ma rifah, 1982), 1:24.

14. Maḥmūd 'Abd al-Majīd al-Khālidī, Qawā' id Nizāam al-Hukm fì al-Islām (Kuwait: Dār al-Buhūth al-'Ilmiyyah, 1980), 219.

15. Hamilton A. R. Gibb, Studies on the Civilization of Islam, ed. Standford J. Shaw and William R. Polk (Princeton: Princeton University Press, 1982), 155.

16. For example, see al-Khālidī, Qawā'id Nizāam al-Hukm fì al-Islām, 224; and alSanhūrī, Fiqh al-Khilāfah, 79, 239.

17. Al-Khālidī, Qawā'id Niz̄ām al-Hukm fì al-Islām, 230-231. 
18. Al-Khālid̄̄, Qawā id Nizāam al-Hukm fì al-Islām, 230-234.

19. Roy Jackson, Mawlana Mawdudi and Political Islam: Authority and the Islamic State (London: Routledge, 2011), 23, 105-106; Seyyed Vali Reza Nasr, "Mawdudi and the Jama at-I Islami: The Origins, Theory and Practice of Islamic Revivalism," In Pioneers of Islamic Revival, ed. Ali Rahnema (London: Zed Books, 1994), 98-124.

20. Leonard Binder, Religious and Politics in Pakistan (Berkeley: University of California Press, 1961), 14.

21. James P. Piscatori, Islam in a World of Nation-States (Cambridge: Cambridge University Press, 1986), 32.

22. Albert Hourani, Arabic Thought in the Liberal Age 1798-1939 (Cambridge: Cambridge University Press, 1983), 5; Binder, Religious and Politics in Pakistan, 14.

23. Muhammad ibn 'Abd al-Karīm al-Shahrastān̄̄, Al-Milal wa-al-Niḥal, ed. Muhammad Sayyid Kaylān̄̄ (Beirut: Dār al-Ma rifah, 1982), 1:24; Muslim Sects and Divisions: The Section on Muslim Sects in Kitāb al-Milal wa'l-Nihal, trans.

A. K. Kazi and J. G. Glynn (London: Kegan Paul International, 1984), 19. The quotation was translated by A. K. Kazi and J. G. Glynn.

24. Muhāammad Abū Zahrah, Al-Wiḥdah al-Islāmiyyah (Beirut: Dār al-Rā'id al'Arabī, 1971), 11, 234-235, 243.

25. Abū Zahrah, Al-Wihdah al-Islāmiyyah, 242-244.

26. See for example, Al-Khālidī, Qawā id Niz̄ām al-Hukm fì al-Islām, 13.

27. Abū al-Husayn Aḥmad ibn Fāris ibn Zakariyyā', Mu'jam Maqāyīs al-Lughah, ed. 'Abd al-Salām Muhammad Hārūn (Beirut: Dār al-Jayl, 1991), 2:210-211; E. W. Lane, Arabic-English Lexicon, (London: Williams and Norgate, 1984), 1:795, 797-798.

28. Al-Rāghib al-Ișfahān̄i, Mufrdāt Alfāz al-Qur'ān, ed. Șafwān 'Adnān Dāwūdī (Damascus: Dār al-Qalam, 1992), 294.

29. Abdul Rashid Moten and Syed Serajul Islam, Introduction to Political Science (Singapore: Thomson Learning, 2005), 207.

30. Ghulam Nabi Ganai, "Muslim Thinkers and their Concepts of Khilāfah," Hamdard Islamicus, 24, no. 1 (2001), 59.

31. Al-Māward̄̄, Al-Aḥkām al-Sulțāniyyah, 5; The Ordinances of Government, 3.

32. 'Abd al-Raḥmān ibn Khaldūn, Muqaddimat Ibn Khaldūn (Beirut: Dār al-Qalam, 1984), 191; The Muqaddimah: An Introduction to History, trans. Franz Rosenthal (Princeton: Princeton University Press, 1967), 1:388. For more definitions, see Ganai, "Muslim Thinkers and their Concepts of Khilāfah," 59-60.

33. Ibn Khaldūn, Muqaddimat Ibn Khaldūn, 218; The Muqaddimah, 1:430.

34. Ibn Khaldūn, Muqaddimat Ibn Khaldūn, 191, 227; The Muqaddimah, 1:388, 465.

35. 'Alyān 'Abd al-Fattāh al-Jālūd̄̄, "Tațawwur Mafhūm al-Sulțanah wa-'Alāqatuhā bi-al-Khilāfah min Imārat al-Istīlā' ' inda al-Māward̄̄ ilā Mafhūm al-'Așabiyyah wa-al-Shawkah 'inda Ibn Khaldūn," Islāmiyyat al-Ma'rifah, 13, no. 51 (2007), 209-239.

36. Al-Māward̄̄, Al-Aḥkām al-Sulțāniyyah, 14; The Ordinances of Government, 16.

37. Ibid.

38. Ganai, "Muslim Thinkers and their Concepts of Khilāfah," 63; Ahmad ArRaysuni, "Thoughts on Islam's Political System," SuhaibWebb.com, 17 September 2010. Retrieved 21 October 2013 from http://www.suhaibwebb.com/ 
islam-studies/islamic-law/thoughts-on-islam $\%$ E2\%80\%99s-political-system

39. Gibb, Studies on the Civilization of Islam, 154-155; Ann K. S. Lambton, State and Government in Medieval Islam: An Introduction to the Study of Islamic Political Theory: the Jurists (Oxford: Oxford University Press, 1985), xvi, 1516; Al-Jālūd̄̄, "Mafhūm al-Sultanah, 209-239.

40. Ibn Jamā'ah, Taḥrīr al-Ahkām fì Tadbīr Ahl al-Islām, 18; Ganai, "Muslim Thinkers and their Concepts of Khilāfah," 65-66.

41. Ar-Raysuni, "Thoughts on Islam's Political System."

42. Al-Ghazālī, Al-Iqtiṣād fì al-I 'tiqūd, 148-149; H. K. Sherwani, "Al-Ghazālī on the Theory and Practice of Politics," Islamic Culture, 9 (1935), 463.

43. Ibn Taymiyyah, Al-Siyāsah al-Shar' iyyah, 82.

44. See for example, 'Alī 'Abd al-Rāziq, Al-Islām wa-Ușul al-Hukm (Cairo: alHay'ah al-Mișriyyah al- 'Āmmah li-al-Kutub, 1993).

45. Ar-Raysuni, "Thoughts on Islam's Political System."

46. AbdulHamid A. AbuSulayman, "Introduction: Islamization of Political Sciences," in Introduction to Political Science, eds. Aldila Bt Isahak and Abdul Rashid Moten (Kuala Lumpur: International Islamic University Malaysia, 1995), xiii.

47. Harvey Cox, The Secular City (New York: Collier Books, 1990), 22.

48. Michael G. Roskin, et al., Political Science: An Introduction (Upper Saddle River, N.J.: Prentice Hall, 2003), 4.

49. Mildred A. Schwartz, A Sociological Perspective on Politics (Englewood Cliffs, N.J.: Prentice Hall, 1990), 2, 17-18.

50. Geoffrey Ponton and Peter Gill, Introduction to Politics, $3^{\text {rd }}$ ed. (Oxford: Blakwell, 1993), 6.

51. Taqī al-Dīn ibn Taymiyyah, Al-Hisbah fì al-Islām (Beirut: Dār al-Fikr alLubnān̄i, 1996), 6; Public Duties in Islam: The Institution of al-Hisbah, trans. Muhtar Holland (London: Islamic Foundation, 1982), 20.

52. Ibn Khaldūn, Muqaddimat Ibn Khaldūn, 41-42; The Muqaddimah, 1:91.

53. Aristotle, The Politics (Cambridge: Cambridge University Press, 1988), Book 1, p. 3.

54. Roskin, Political Science: An Introduction, 5.

55. Nevil Johnson, The Limit of Political Science (Oxford: Clarendon Press, 1989), 6.

56. 'Abd al-Majīd al-Najjār, Khilāfat al-Insān Bayn al-Wahy wa-al-'Aql (Herndon: International Institute of Islamic Thought, 1992), 63-64.

57. Muhammad ibn Yūsuf Abū Hayyān al-Gharnāțî, Al-Bahr al-Muhìt fì Tafsīr alQur'ān (London: British Library, $18^{\text {th }}$ century Manuscript), interpretation of verse $2: 30$.

58. Patricia Crone, God's Caliph: Religious Authority in the Century of Islam (Cambridge: Cambridge University Press, 1986), 5.

59. Aḥmad Hasan Farḥāt, Al-Khilāfah fì al-Arḍ (Amman: Dār 'Ammār li-al-Nashr, 2002), 14, 16.

60. Quoted by Abū Ja 'far ibn Jarīr al-Ṭabarī, Jāmi al-Bayān fì Tafsīr al-Qur'ān (Beirut: Dār al-Ma rifah, 1983), 1:156.

61. 'Abd al-Raḥmān ibn Ibrāhīm al-Mațrūd̄̄, Al-Insān: Wujūduhu wa-Khilāfatuhu fì al-Arḍ fì Daw' al-Qur'ān al-Karīm (Cairo: Maktabat Wahbah, 1990), 343. 